\title{
GEMBALA: ANTARA SEORANG PELAYAN DAN PEMIMPIN
}

\begin{abstract}
Abstraksi
Panggilan gembala dalam perjanjian lama selalu berbicara tentang pekerjaan untuk menjaga kambing, domba, lembu atau binatang peliharaan. Pekerjaan ini termasuk pekerjaan yang hina dalam bangsa Israel dan bangsa lainnya. Masa itu biasanya menjadi tentara atau saudagar lebih layak di bandingkan dengan gembala. Di tanah Mesir sendiri, pekerjaan ini menjadi sesuatu yang sangat hina dan tidak beradab. Selalunya setiap penugasan seorang pendeta atau gembala dalam gereja adalah untuk menggembalakan jiwa jiwa yang Tuhan percayakan kepada mereka untuk dilayani kehidupan rohani. Namun sering kali pelayanan ini menimbulkan konotasi makna bahwa mengembalakan itu harus senantiaa menjadi seorang hamba yang identik sekali dengan tanpa hak, tanpa harta, hina dan tidak mempunyai kuasa atas otoritas atas jemaat yang dilayani. Sehingga banyak sekali gembala hanya berfungsi sebagai "pembicara hari Minggu" atau seseorang yang berfungsi dalam doa, konseling pastoral bahkan hanya diperlukan untuk urusan - urusan yang hanya bersifat rohani.

Pada akhirnya dengan perkembangan zaman dan kehidupan jemaat makin lama makin kompleks, sangat rumit dan tekanan tekanan dunia yang menyerang iman, harap dan kasih mereka kepada Tuhan. Oleh sebab itu di perlukanlah seorang gembala yang bukan saja mempunyai hati hamba untuk selalu dapat melayani mereka dalam hal hal kerohanian namun juga bisa berdiri dan bertindak sebagai seorang pemimpin rohani. Walalupun gembala itu adalah seorang pemimpin bukan berarti dia menjadi boss atau manager karena dalam saat yang bersamaan juga, gembala itu harus dapat mengambil fungsi sebagai seorang pelayan Tuhan yang diurapi. Gereja sekarang ini telah banyak mengalami kemerosotan fungsi gembala dalam pelayanan mereka, hal ini disebabkan karena ketidak-seimbangan antara fungsi pelayan dan pemimpin yang mereka emban.
\end{abstract}

\section{PENDAHULUAN}

Alkitab menuliskan dengan jelas tentang jawatan dalam pelayanan zaman akhir ini. Selain dari pada Nabi, Rasul, Penginjil dan Pengajar maka tugas yang tidak kalah penting dan mendapat proporsional yang "sedikit' lebih ditekankan adalah jawatan Gembala. Musa adalah Gembala Israel di padang gurun selama 40 tahun. Daud adalah Gembala sekaligus Raja Israel di tanah perjanjian juga selama 40 tahun. Nehemia adalah Gembala Israel saat pembangunan rumah Allah di Yerusalem dari 
tanah perbudakan. Bahkan Gembala Agung kita Yesus Kristus Tuhan lahir ke dunia dan melayani manusia untuk mengembalakan mereka.

John 21:15-18 ${ }^{15}$ Sesudah sarapan Yesus berkata kepada Simon Petrus: "Simon, anak Yohanes, apakah engkau mengasihi Aku lebih dari pada mereka ini?" Jawab Petrus kepada-Nya: "Benar Tuhan, Engkau tahu, bahwa aku mengasihi Engkau." Kata Yesus kepadanya: "Gembalakanlah domba-dombaKu." ${ }^{16}$ Kata Yesus pula kepadanya untuk kedua kalinya: "Simon, anak Yohanes, apakah engkau mengasihi Aku?" Jawab Petrus kepada-Nya: "Benar Tuhan, Engkau tahu, bahwa aku mengasihi Engkau." Kata Yesus kepadanya: "Gembalakanlah domba-domba-Ku." 17 Kata Yesus kepadanya untuk ketiga kalinya: "Simon, anak Yohanes, apakah engkau mengasihi Aku?" ... Dan ia berkata kepada-Nya: "Tuhan, Engkau tahu segala sesuatu, Engkau tahu, bahwa aku mengasihi Engkau." Kata Yesus kepadanya: "Gembalakanlah domba-domba-Ku

Tugas penggembalaan ini pertama kali ditunjukkan kepada jiwa jiwa dalam sebuah bangsa pilihan, kepada pribadi pribadi bahkan juga kepada kumpulan kumpulan manusia dan persekutuan persekutuan. Baik itu dalam jumlah yang sangat besar (ruang lingkup bangsa) sampai hanya dua tiga orang saja. Baik yang bersifat jangka panjang maupun jangka pendek. Ada banyak sekali item item dan ketentuan ketentuan mengenai tugas dan tanggung jawab, kualifikasi seorang gembala, proses dan tantangan tantangan yang kan dihadapi.

Alkitab mencatat bahwa tugas penggembalaan ini sangat kompleks, cenderung rumit sehingga perlu kerja keras dan hati hamba, detail dan memerlukan pengabdian tinggi. Gambaran dunia mungkin hampir sama dengan profesi dokter jasmani. Gembala mungkin seperti dokter batiniah atau atau dokter rohani. Hal ini bisa ditunjukkan oleh dua kebenaran Firman Tuhan:

Maz 23:1-6, Mazmur Daud. TUHAN adalah gembalaku, takkan kekurangan aku. ${ }^{2}$ la membaringkan aku di padang yang berumput hijau, la membimbing aku ke air yang tenang; ${ }^{3}$ la menyegarkan jiwaku. la menuntun aku di jalan yang benar oleh karena nama-Nya. 4 Sekalipun aku berjalan dalam lembah kekelaman, aku tidak takut bahaya, sebab Engkau besertaku; gada-Mu dan tongkat-Mu, itulah yang menghibur aku. ${ }^{5}$ Engkau menyediakan hidangan bagiku, di hadapan lawanku; Engkau mengurapi kepalaku dengan minyak; pialaku penuh melimpah. ${ }^{6}$ Kebajikan dan kemurahan belaka akan mengikuti 
aku, seumur hidupku; dan aku akan diam dalam rumah TUHAN sepanjang masa.

Tugas seorang gembala sangat jelas diterangkan dalam ayat ini dari memberi air minum, penjagaan sepanjang jalan, pengajaran dan didikan, penyediaan berkat jasmani dan makanan, pembelaaan terhadap musuh, pengurapan dan promosi sampai kasih setia dan kemurahan. Menurut orang awam hal ini bukanlah hal yang mudah. Namun Raja Daud telah menikmati karya penggembalaan ini saat dia mengenal dengan baik Tuhan yang Dia sembah dan Dia layani dari masa mudanya di padang gurun.

Alkitab Perjanjian Baru dalam Yohanes 21:15 -18 seperti tertulis di atas menuliskan hal yang sedikit lebih formal dan tegas tentang tugas penggembalaan ini. Disitu ada tugas memberi tempat berteduh, memberi makan dan memberi penghiburan dan kekuatan. Yesus memberi perintah khusus dan jelas kepada Petrus dalam mengembalakan jiwa jiwa yang Dia tinggalkan. Dan dalam hitungan singkat setelah hari Pentakosta, Petrus menjadi gembala pertama untuk gereja Tuhan di kota Yerusalem.

\section{METODE PENELITIAN}

Penelitian ini dibatasi observasi penulis, Juga dipakai metoda analisis literatur (Library Research) yaitu menganalisis buku - buku yang berhubungan dengan "Penggembalaan Jemaat" dan juga "Kepemimpinan"."

\section{ANTARA PELAYANAN DAN KEPEMIMPINAN}

Awal mula tugas Penggembalaan lebih banyak ditekankan kepada segi pelayanan, hati hamba untuk memperhatikan jiwa dalam kerohanian untuk mengenal 
Tuhan dengan benar, namun juga harus menuntun mereka untuk hidup dalam segi jasmani yang mencukupi. Tidak lupa juga mempersiapkan pengajaran buat mereka untuk tidak goyah dalam menghadapi dunia dengan segala tipu dayanya.

George Barna dalam pendahuluannya di buku A Fish Out of Water menjelaskan tentang urutan kepemimpinan. Pertama, seseorang harus memahami dengan benar tentang panggilan Tuhan dalam hidupnya untuk memimpin. Karena tidak semua orang diberi amanah untuk memimpin. Setelah itu dia harus mengerti dan arti kepemimpinan yang sebenarnya karena dia harus tahu fitrah yang bisa menggerakkan orang lain untuk bisa meneruskan segala hal mengikuti kamu. Dan selama Anda memimpin, kompetensi kepemimpinan harus ditunjukkan secara maksimal agar orang lain yang Anda pimpin juga bisa maksimal juga. Sehingga sudah saatnya setiap pemimpin cepat atau lambat menghadapi konsekuensi yang besar bagi kepemimpinannya $^{1}$

Setelah kisah jemaat mula mula dengan pertumbuhan yang luar biasa di Yerusalem dan kota sekitar, maka beberapa abad kemudian kekristenan mencapai jumlah yang sangat besar. Jumlah gereja sangat banyak dan tersebar di seluruh dunia. Dan sejalan dengan itu maka gembala gembala baru di bentuk baik lewat sekolah tinggi teologia maupun sekoloh misi internal gereja itu sendiri. Gembala gembala baru mulai menempati pos pelayanan mereka masing masing. Baik mereka yang baru meneruskan pelayanan ini atau mereka yang memulai pelayanan ini dari awal sekali dengan satu atau dua jiwa. Apapun awal pelayanan mereka dan latar belakang sekolah formal atau sekolah misi yang mereka belajar, tempat dan besarnya jumlah jiwa yang mereka layani atau bahkan kondisi dan fakta fakta dilapangan

1 George Barna, "A Fish Out of Water” (Jakarta: Immanuel, 2004), page xi-xiv 
seharusnya tugas pengembalaan yang telah di catat oleh alkitab tetap terus di jaga kualitasnya.

Hal ini sesuai dengan bagaimana Paulus juga membangun pelayanannya menjadi pemimpin. Semasa hidupnya sebagai rasul, Paulus telah begitu aktif terlibat dalam pelayanan pekabaran Injil bahkan tidak jarang, buahnya adalah sebuah jemaat baru. Tiga kali bahkan empat perjalanan misinya bukanlah pekerjaan yang sia-sia, sebaliknya telah membuahkan banyak jemaat baru serta lebih dari itu telah mengokohkan keyakinan beberapa di antaranya²

Hari ini dunia sedang menantikan fungsi yang maksimal oleh gembala gembala. Carl George (1993) dan oleh Peter Wagner (1995) memberikan definisi yang nyata bahwa gembala sebagai pemimpin yang melayani harus mampu menjadi seorang equipper, yakni seseorang pemimpin yang melengkapi jemaat atau pemimpin pelengkap ${ }^{3}$.

Secara pelayanan gereja dan jiwa jiwa tidak perlu kuatir dengan pemenuhan pelayanan penggembalaan. Sepertinya dunia bisa berharap akan bisa menikmati kehidupan rohani lebih sehat, progresif dan bertumbuh ke arah Kristus. Ada solusi yang diberikan lewat mereka kepada anak muda dan jemaat yang mengalami ketakutan, kekuatiran akan masalah hidup, tekanan merajalela, pengaruh negatif dan sesat dari media teknologi. Namun apa yang di ajarkan oleh Tuhan lewat kebenaran Firman nya yang menjadi acuan dan tolak ukur pelayanan seorang gembala yang efektif, efisien dan berpengaruh ternyata justru sedang menuju titik nadir, cenderung mundur dan bahkan jauh dari kriteria kriteria awal yang sudah di ajarkan sekarang ini.

2 Pieter G.O Sunkudon, Pilar- Pilar Kokoh Penopang Gereja (Palu : Sekolah Tinggi Teologi Injili Indonesia (STTII) Palu, Cetakan Pertama Mei 2013), Halaman 14

3 Peter Wagner, Memimpin Gereja Anda Bertumbuh (BPK Gunung Mulia: Malang, 1995 ), halaman 83-84. 
Ketimpangan ahlak dan integritas para gembala sudah mulai banyak terjadi dalam dunia rohani. Rumah Tuhan mulai terdengar berita berita miring dalam berita nasioanal dan internasional. Salah satu contoh seorang gembala bernama Jim Howard, salah satu pendeta di Kampus Valencia yang merupakan bagian dari Real Life Church (RLC) California ditemukan tewas di rumahnya dengan luka tembak di bagian kepala pada hari Rabu, 23 Januari 2019 lalu. Dan ternyata gembala ini melakukan bunuh diri karena depresi. Ada lagi pemimpin gereja Inland Hills, California, Pendeta Andrew Stoecklein memutuskan untuk mengakhiri hidupnya dengan bunuh diri pada Sabtu, 25 Agustus 2018 lalu. Kabar inipun membuat jemaat gerejanya terpukul dan begitu berduka. ${ }^{4}$

Dari Negara lainnya yakni Prancis seorang pendeta Prancis Pierre-Yves Fumery, berusia 38 tahun ditemukan tewas gantung diri di sebuah gereja presbiterian di kota Gien, di sekitar lembah Loire. Kabar ini menyebar setelah tubuhnya ditemukan tak bernyawa pada hari Sabtu, 20 Oktober 2018. Dari hasil penyelidikan ditemukan bahwa pendeta itu memutuskan bunuh diri setelah dituduh melakukan tindakan pelecehan seksual terhadap gadis di bawah umur. ${ }^{5}$

Sebagai pelayan Tuhan ternyata banyak gembala yang bersikap salah dalam praktek. Bukan saja hal etika yang dilanggar namun juga tentang hal hal menyangkut integritas dan juga panggilan itu sendiri.

Penelitian selama 18 tahun oleh seorang pengamat kekristena R. J. Krejcir ternyata banyak sekali faktor yang menyebabkan seorang gembala menjadi hilang

\footnotetext{
${ }^{4}$ Iori Mora , "Disayangkan Pendeta California Putuskan Bunuh Diri Karena Alasan Ini", (https://www.jawaban.com/di akses tanggal 31 January 2019)

5.Danu Damarjati, "Terjadi Lagi, Pastor di Prancis Bunuh Diri usai Tuduhan Pencabulan", (https://news.detik.com/di akses tanggal 23 Okotober 2018)
} 
kapasitasnya, otoritasnya dan berujung kepada pelecehan seksual, etika moral bahkan bunuh diri.

Remember, churches fail because we as pastors fail; we tend to place our needs and desires over the Lord's. It is His Church and we are His servant. Let our focus be on the right target-that is, His Way and not ours! We are called to a higher purpose. We are not called to ourselves. We are to lead others to Him, not to our self. Ministry is a wondrous call, it can be joyful and fulfilling; it is also a dangerous thing because we are before a Holy God. Yes, we have grace, but we have a responsibility too! ${ }^{6}$

Dari penelitian terbaru yang dilakukan terhadap 1050 pendeta disurvei dari dua konferensi pendeta yang diadakan di Orange County dan Pasadena, Ca-416 pada 2005, dan 634 pada 2006 Ada beberpa sebab yang sangat signifikan. Hal tersebut adalah:

1. Tujuh ratus sembilan puluh (790 atau $75 \%$ ) dari para pendeta yang kami survei merasa bahwa mereka tidak memenuhi syarat dan / atau kurang terlatih oleh seminari mereka untuk memimpin dan mengelola gereja atau menasihati orang lain. Ini membuat mereka berkecil hati dalam kemampuan mereka sebagai pendeta.

2. Tujuh ratus lima puluh enam (756 atau $72 \%$ ) dari para pendeta yang kami survei menyatakan bahwa mereka hanya mempelajari Alkitab ketika mereka sedang mempersiapkan khotbah atau pelajaran. Ini menyisakan hanya $38 \%$ yang membaca Alkitab untuk kebaktian dan pelajaran pribadi.

3. Delapan ratus dua (802 atau $71 \%$ ) dari para pendeta menyatakan bahwa mereka kelelahan, dan mereka memerangi depresi tanpa kelelahan setiap minggu dan bahkan setiap hari.

Hal lainnya yang patut menjadi perhatian

${ }^{6}$ R. J. Krejcir Ph.D. Francis A. Schaeffer, "Statistic On Pastor", (http://www.intothyword.org) 
1. $15 \%$ pendeta meninggalkan pelayanan setiap bulan karena kegagalan moral, kelelahan rohani, atau pertikaian di gereja-gereja mereka

2. $80 \%$ pendeta merasa tidak memenuhi syarat dan berkecil hati dalam peran mereka sebagai pendeta.

3. $70 \%$ pendeta terus memerangi depresi dalam hidup mereka

Hal yang boleh dikategorikan mengerikan adalah sebuah kesimpulan dari R. J. Krejcir yang mengatakan bahwa angka statistik menunjukkan 60\% hingga $80 \%$ dari mereka yang memasuki pelayanan tidak akan tetap berada di dalamnya 10 tahun kemudian, dan hanya sebagian kecil yang akan tetap di dalamnya sebagai karier seumur hidup. Hampir 90\% pendeta memulai langsung dengan panggilan sejati dan antusiasme serta ketekunan iman untuk menggembalakan, tetapi sesuatu terjadi untuk menggagalkan kereta gairah dan cinta mereka untuk panggilan itu.

Thom Rainer membuat sebuah kesimpulan dari 200 komunikasi Tanya jawab lewat media telepon yang dilakukan terhadap para gembala, ada delapan hal yang menjadi sebab seorang gembala berjuang keras dalam mempertahankan pelayanannya untuk tetap baik ke masa depan. Hal tersebut adalah: pertama, adalah kritik dan konflik yang semakin besar dan kompleks. Yang kedua adalah masalah. Banyak pendeta berjuang dengan nilai nilai dan harapan yang dibuat oleh anggota gereja kepada istri atau anak-anak mereka. Sehingga banyak keluarga pendeta berjuang dengan sindrom "rumah kaca".

Hal yang ketiga adalah stress (tekanan demi tekanan hidup). Kehidupan pastor adalah kehidupan yang penuh suka dan duka emosional. Ada kritik dan penggemar yang memujanya. Satu saat akan ada harapan dari anggota gereja yang bisa tidak masuk akal kepadanya. Sifat panggilan pastor untuk melayani dapat memberikan tekanan yang tampaknya tak berkesudahan. Hal selanjutnya yang keempat adalah 
Depresi. Depresi meresap dalam pelayanan pastoral. Dan sering kali masalah "rahasia".

Hal yang kelima adalah kelelahan. Pelayanan penggembalaan kadang bisa membuat "gila pelayanan". Sampai tidak sedikit seorang gembala bisa menghabiskan 70 jam/ minggu untuk melayani jiwa atau ada di gereja. . Hal yang keenam masalah seksual. Biasa nya adalah kategori: pornografi atau ketidaksetiaan dalam pernikahan. Selanjutnya ketujuh masalah keuangan. Sebagian besar dunia mendengar tentang beberapa pendeta yang membuat gaji besar. Kenyataannya adalah bahwa mayoritas pendeta berjuang secara finansial. Dan masalah kedelapan yang terakhir sekali adalah masalah manajemen waktu. Harapan jemaat untuk para gembala bisa jadi tidak realistis. Bagaimana tidak? Para gembala harus datang menghadiri banyak pertemuan, mengunjungi banyak jemaat, belum lagi kelas kelas kepemimpinan strategis, pelayanan pernikahan dan pemakaman, dan untuk terlibat dalam komunitas. Dan satu lagi yang persiapannya panjang yakni “kotbah”. Banyak gembala tidak tahu utnuk mengatakan "tidak." Belum lagi kelemahan gembala untuk tidak pandai mendelegasikan beberapa pelayanan mereka kepada orang lain. ${ }^{7}$

Kebanyakan pendeta menyukai panggilan mereka. Kebanyakan pendeta menikmati sebagian besar dari apa yang mereka lakukan dalam pelayanan. Dan kebanyakan pendeta tidak akan mengubah peran mereka jika mereka bisa. Tetap saja, banyak pendeta memiliki tantangan dan pergumulan yang berkelanjutan. Dan banyak orang akan dengan senang hati menerima bantuan dari anggota gereja, katakata penghiburan dari kebanyakan orang, dan pengetahuan bahwa orang lain berdoa untuk mereka.

\footnotetext{
${ }^{7}$ Thom Rainer, "The Number One Reason For The Decline In Church Attendance And Five Ways To Addres It" (https://thomrainer.com/ diakses tanggal 19 Agustus 2013)
} 
Permasalahan yang muncul dan menjadi perhatian sekarang ini adalah pertama apakah seorang Gembala itu adalah murni seorang pelayan Tuhan yang melayani gereja dan jiwa jiwa yang digembalakan dengan hak yang minim dan kewajiban yang besar baik kepada Tuhan dan kepada jiwa jiwa? Hal yang kedua adalah seberapa jauh nilai dan tingkatan seorang Gembala untuk bisa berdiri menjadi seorang pemimpin di gerejanya dengan penuh tanggung jawab dan integritas terhadap harapan dan espektasi tinggi dari jemaatnya? Dan yang terakhir adalah bagaimana implementasi perpaduan antara pelayanan dan kepemimpinan Gembala dalam lokal sehingga maksimal dan bertahan sampai akhir hayatnya?

\section{HASIL DAN SEBUAH KONSEP}

Hal yang harus diletakkan dengan jelas sekarang ini adalah apa yang bisa dilakukan oleh seorang gembala dalam posisinya sebagai pelayan Tuhan yang efektif dan efisien dalam gereja lokal dan lingkungan keluarga dikehidupan sehari hari. Kesemuanya ini setidaknya akan memberikan sebuah perspektif yang tepat kepada seorang gembala supaya semangatnya terus membara dalam memimpin namun dengan hati hamba. Alkitab mencatat tentang prinsip pelayanan jemaat kepada Daud, yakni:

Mazmur 78:70 - 7270 dipilih-Nya Daud, hamba-Nya, diambil-Nya dia dari antara kandang-kandang kambing domba; ${ }^{71}$ dari tempat domba-domba yang menyusui didatangkan-Nya dia, untuk menggembalakan Yakub, umat-Nya, dan Israel, milik-Nya sendiri. ${ }^{72}$ la menggembalakan mereka dengan ketulusan hatinya, dan menuntun mereka dengan kecakapan tangannya.

Erwin Lutzer dalam bukunya Pastor to Pastor setidaknya menekankan tentang meresponi panggilan penggembalaan di zaman yang terus berubh ini adalah punya keyakinan teguh dalam memimpin. Kualitas hati dan nilai etika moral serta motivasi kudus dan tulus dari Allah itu sendiri harus selalu terjaga. Hal kedua adalah menyangkut tentang kekuatan panggilan itu dalam koridor kebenaran Firman Tuhan. 
Alkitab mencatat tentang spesifikasi yang jelas dalam panggilan pelayanan ini dalam 1 Timotius 3. Dan spesifikasi ini hatus sudah dapat dipenuhi dari awal pelayanan itu sendiri. Dan terakhir tentu saja adanya dukungan yang aktif dari jemaat Tuhan itu sendiri yang menjadi patner penggembalaan dalam gereja lokal ${ }^{8}$.

Alkitab menjelaskan bagaimana Daud mendapatkan mandapatkan mandat pelayanan seorang gembala untuk bangsa yang bsangat besar namanya Israel. Meskipun dia adalah seorang anak biasa tanpa punya pengalaman berperang seperti seorang tentara bahkan hanya seorang muda yang masih "labil" dalam psikologi perkembangan nya, namun Tuhan meracang Daud dari umur remaja, diurapi oleh Samuel untuk bersiap menjadi Raja menggantikan Saul pendahulunya. Bagaimana alkitab menjelaskan dengan secara teliti kehidupan Daud yang memenuhi syarat untuk menjadi Gembala buat bangsanya.

Setelah Tuhan menolak keturunan Yusuf untuk meneruskan tongkat kerajaan Israel (Maz 78:67): ... menolak kemah Yusuf, dan suku Efraim tidak dipilihNya tetapi la memilih suku Yehuda, gunung Sion yang dikasihi-Nya; maka tongkat estafet turun kepada suku Yehuda. Tuhan akan membangun bangsa pilihannya dengan kualitas yang hebat. Banyak orang tidak memahami pelayanan penggembalaan ini mempunyai standar yang sangat tinggi di mata Allah. Dalam pengalaman kecil penulis di satu gereja Pantekosta di Indonesia, kebanyakan para gembala yang berbicara didepan mimbar, pengisi seminar anak muda ataupun ibadah youth diisi oleh hamba Tuhan yang menggembalakan namun tidak sekolah tinggi. Beberapa tahun kemudian penulis mendapat kesempatan untuk bisa berjumpa dengan beberapa gembala sidang atau gembala jemaat sepenuh waktu. Penulis mengamat amati secara

\footnotetext{
${ }^{8}$ Erwin Lutzer, "Pastor to Pastor" ( Malang : Gandum Mas, 2010), halaman 12-15.
} 
seksama bagaimana pola, strategi penggembalaan mereka di gereja lokal. Ada banyak keluhan dan juga ketidak puasan tersendiri yang muncul dari jemaat lokal terhadap kepemimpinan dan penggembalaan mereka.

Sebenarnya Alkitab telah memberikan penekanan khusus untuk tugas penggembalaan ini. Mazmur 78; 69 mengatakan bahwa "la membangun tempat kudusNya setinggi langit, laksana bumi yang didasarkan-Nya untuk selama-lamanya". Kualitas seseorang yang mengeembalakan bangsa Israel, bangsa pilihannya adalah punya kapasitas seperti membangun tempat kudus setinggi langit. Ini bicara tentang gambaran pelayanan seperti surge dalam kekekalansurga, kemuliaan Allah yang akan bersemayam bersamanya. Sedangkan bagian ayat selanjutnya menyakan bahwa dasar dasar pelayanan penggembalaan di bumi ini selama lamanya. Kita semua tahu bahwa bumi dan segala isinya tidak kekal alias sementara Namun bila berbicara pelayanan manusia dalam penggembalaan, sifat pelayanan ini ternyata diperhitungkan kekal. Hal ini menandakan bahwa Tuhan tidak pernah menyesal untuk membangun bangsa pilihannya menjadi sebuah contoh tersendiri. Bangsa ini digembalakan harus dengan cara bangsa yang berbeda dan dipersiapkan untuk menerima kemuliaan Allah. Demikian juga dalam pembangunan gereja lokal yang adalah manifestasi Kerajaan Surga di bumi ini. Menjadi sebuah tugas dan tanggung jawab yang besar dan penuh kasih ilahi untuk setiap gembala dapat menyelesaikan tugas mulia ini. Membangun setiap pribadi, manusia percaya Kristus sampai komunitas yang ilahi untuk sampai kepada kesempurnaan Allah sejak di bumi. Karena jujur harus diakui bahwa gereja Tuhan yang tersebar di seluruh dunia ini tidak semua mempunyai standar pelayanan sesuia alkitab. Tidak sedikit yang sudah lari dari tujuan awal pelayanan. Gereja bukan lagi menjadi organisme yang dipenuhi dengan pertobatan tetapi liturgis dan aturan. Gereja tidak bisa lagi menerima kegerakan rohani 
yang baru dan sedikit berbeda dari hal hal yang lumrah sudah terjadi karena organisasi melarangnya.

Pribadi gembala yang dipanggil dalam tugas panggilan khusus pada awalnya setia, penuh pengabdian dan cinta Tuhan namun seiring dengan waktu dengan segala tantangan kehidupan, perkembangan zaman yang semakin modern namun pada akhirnya tidak sedikit yang motivasi nya sudah berubah. Integritas kepemimpinan menjadi luntur. Prinsip kebenaran Firman Tuhan telah menjadi sesuatu yang bisa di beli. Kompromi akan dosa mulai menyebar dalam lembaga gereja dan juga kepada pendeta dan pengurusnya

Pertanyaan besar sekarang ini adalah adalah siapakah pribadi manusia yang cocok dan mampu untuk menjaga nilai kualitas yang begitu tinggi yang Tuhan sendiri telah tentukan sebelumnya bagi bangsa Israel. Ternyata didapati Daud. Apa yang Daud akan lakukan? Fakta apa yang dalam kehidupan Daud di dapati sesuai dengan syarat ketentuan Allah? Dan kriteria apa yang Tuhan mau untuk Daudlakukan dalam pelayanan penggembalaannya untuk bangsa Israel?

Pertama adalah dikatakan diambilnya Daud dari antara kandang kandang kambing domba. Ternyata Tuhan sangat suka dengan gaya hidup Daud yang sederhana dan apa adanya. Sudah biasa zaman itu untuk anak remaja menggembalakan domba. Namun Daud melakukan nya sedikit lebih. Dari kandang domba yang satu ke kandang domba yang lain, dari kandang kambing yang satu ke kandang kambing yang lain bahkan berpindah dari kandang domba ke kandang kambing. Hal yang menjadi perhatian adalah ternyata dia bukan bertanggung jawab untuk semua kambing domba yang ada didalamnya. Alkitab mencatat dia hanya bertanggung jawab untuk 2-3 ekor domba.

1 Samuel 17:28 Ketika Eliab, kakaknya yang tertua, mendengar perkataan Daud kepada orang-orang itu, bangkitlah amarah Eliab kepada Daud sambil berkata: 
"Mengapa engkau datang? Dan pada siapakah kautinggalkan kambing domba yang dua tiga ekor itu di padang gurun? Aku kenal sifat pemberanimu dan kejahatan hatimu: engkau datang ke mari dengan maksud melihat pertempuran."

Zig Ziglar pernah mengatakan kunci keberhasilan dari orang orang yang biasa menjadi orang yang luar biasa adalah berikan sedikit ekstra atau sedikit lebih. Bagian apa saja yang bisa kita lakukan sedikit lebih ekstra hingga menjadi pribadi yang lebih baik lagi? Ziglar katakana lakukan sedikit lebih untuk usaha atau pekerjaanmu, untuk waktu-waktu terbaikmu. Berikan sedikit waktu yang lebih untuk orang lain yang memerlukan pertolonganmu. Berikan fokus sedikit lebih untuk satu perubahan penting dalam hidupmu. Luangkan waktu sedikit lebih untuk melatih pola pikirmu, dan bahkan berikan sesuatu yang lebih untuk sikap terbaikmu dan juga untuk perencanaan masa depanmu. ${ }^{9}$

Daud punya integritas yang sangat tinggi dalam panggilannya sebagai gembala. Hal ini dibuktikan saat Nabi Samuel di suruh Allah untuk mengurapi raja Israel yang baru dari keluarga Isai di Betlehem. Semua anak Isai sudah lewat depanNabi Samuel kecuali Daud. Dimanakah Daud? ternyata daud sedang ada dalam posisi menggembalakan domba. Daud setia dengan panggilan dan tugas tanggung jawabnya.

1 Samuel 16:11 1 Lalu Samuel berkata kepada Isai: "Inikah anakmu semuanya?" Jawabnya: "Masih tinggal yang bungsu, tetapi sedang menggembalakan kambing domba." Kata Samuel kepada Isai: "Suruhlah memanggil dia, sebab kita tidak akan duduk makan, sebelum ia datang ke mari."

Alkitab menyatakan Daud harus di jemput terlebih dahulu sebelum di urapi oleh

Samuel. Penulis melihat sebagai sebuah keunikan tersendiri dari panggilan seorang

Daud. Dia sangat special dan memang dipersiapkan oleh Tuhan dengan cara yang

${ }^{9}$ Zig Ziglar, "Better than Good "(Integrity Publisher; Tennese: 2006) hal 140. 
ajaib di padang gurun. Apa yang dari unik dari proses pemilihan Daud dalam keluarg Isai?

Pertama; Daud tidak mangalami proses pengudusan dan undangan special seperti yang dilakukan Isai kepada saudaranya yang lain. 1 Samuel 16:5 Kemudian ia menguduskan Isai dan anak-anaknya yang laki-laki dan mengundang mereka ke upacara pengorbanan itu. Apa arti dari pengudusan?

1Petrus 1:2 "Yaitu orang-orang yang dipilih, sesuai dengan rencana Allah, Bapa kita, dan yang dikuduskan oleh Roh, supaya taat kepada Yesus Kristus dan menerima percikan darah-Nya. Kiranya kasih karunia dan damai sejahtera makin melimpah atas kamu."

Pengudusan (Yun. hagiasmos) berarti menjadikan kudus, menahbiskan, memisahkan dari dunia, dan dijauhkan dari dosa supaya kita dapat mempunyai persekutuan yang erat dengan Allah dan melayani Dia dengan sukacita. Daud tidak mengalami hal pengudusan ini.

Kedua adalah Daud juga tidak diundang untuk hadir dalam persembahan korban kepada Allah oleh Nabi Samuel bersama Isai dan keluarga. Memang Isai tidak mengetahui pasti tujuan Samuel dalam acara ini. Namun mengingat dari delapan orang anak Isai namun ternyata ada satu yang dilupakan mereka, hal ini ada kesan tersamar menunjukkan pribadi Daud sedikit di rendahkan. Alkitab mengatakan bahwa Daud tidak berada jauh dari rumah Isai, namun keluarganya sengaja melupakannya. Mungkin hal ini juga yang menjadi dasar tulisan Daud tentang masa kecilnya yang seperti terlupakan oleh keluarganya sendiri dalam Mazmur 27;10, "Sekalipun ayahku dan ibuku meninggalkan aku, namun TUHAN menyambut aku."

Ketiga ternyata acara makan malam ini terhambat karena ketidak-hadiran Daud. Nabi Samuel meminta untuk Daud dijemput makan bersama. Biasanya dalam tradisi keluarga di banyak tempat termasuk Israel, anak bungsu itu selalu dimanjakan atau mendapat perlakuan khusus dan special. Namun agak berbeda dengan Daud. 
Dia terlupakan dan disepelekan untuk acara yang besar seperti ini. Daud ada di padang menjaga domba dan letaknya tidak begitu jauh dari rumah, namun keluarganya melupakan dia untuk acara penting seperti ini. Sehingga Tuhan perlu memberi sebuah tanda selanjutnya kepada Samuel untuk peka dan tahu apa yang menjadi pilihan Allah.

1 Samuel 16:7 "Tetapi berfirmanlah TUHAN kepada Samuel: "Janganlah pandang parasnya atau perawakan yang tinggi, sebab Aku telah menolaknya. Bukan yang dilihat manusia yang dilihat Allah; manusia melihat apa yang di depan mata, tetapi TUHAN melihat hati."

Ternyata pemilihan Daud menjadi seorang pemimpin yang nantinya akan menggembalakan Israel sudah terlihat dari sebelumnya. Para pemimpin Israel yang adalah hamba Saul juga telah melihatnya. Dalam kisah 1 Samuel 16: 14-23 diceritakan bagaiman Daud bisa sampai ke istana raja Saul. Satu saat setelah Roh Tuhan pergi dari Saul maka Saul selalu diganggu oleh roh jahat. Ada seorang hamba Saul memberikan sebuah ide untuk mendatangkan pemain kecapi hanya untuk mengibur raja. Sebenarnya banyak pemain kecapi di Israel pada waktu itu. Namun ada yang berbeda dengan Daud.

1 Samuel 16:18 "Lalu jawab salah seorang hamba itu, katanya: "Sesungguhnya, aku telah melihat salah seorang anak laki-laki Isai, orang Betlehem itu, yang pandai main kecapi. la seorang pahlawan yang gagah perkasa, seorang prajurit, yang pandai bicara, elok perawakannya; dan TUHAN menyertai dia."

Penilaian pegawai istana Saul terhadap Daud sungguh diluar dugaan. Walaupun hanya seorang muda dengan 2 - 3 ekor domba namun telah membuat orang orang "penting " merasa terpanggil untuk mempromosikan Daud pada waktu yang tepat. Kriteria dasar penilannya adalah Daud itu selain pemain kecapi juga dalah seorang pahlawan. Mereka mendengar kisah kisah yang spektakuler dari mulut ke mulut tentang kepahlawanan Daud dalam menghadapi binatang buas yang berusaha menerkam kambing dombanya. Hal inilah jugalah yang pernah diceritakan oleh Daud 
tentang pengalamannya saat di "interview" oleh Raja Saul sebelum menghadapi Goliat. Bagaimana Daud menghadapi singa dan beruang, menghajar binatang binatang itu dengan tangan kosong tanpa senjata tajam. Dikejar nya binatang binatang itu walaupun dari ukuran kecepatan dan ukuran sangat jauh berbeda, lalu dihajarnya dan dilepaskan domba dari mulut binatang itu. Kalaupun binatang binatang itu kembali menyerangnya, maka Daud menangkap janggut, menghajarnya untuk kedua kali dan bahkan membunuhnya (1 Samuel 16: 34-37).

Hal penilaian lainnya adalah Daud itu punyakarakter seperti seorang prajurit. Alkitab tidak pernah menyatakan bahwa Daud pernah menjadi prajurit kerajaan sebelum berjumpa dengan Saul. Namun tindak tanduk dan kemampuan dari Daud terlihat sekali seperti prajurit. Hal ini bisa dipahami karena tiga abang Daud juga adalah prajurit Saul. Mungkin cerita abang abangnya saat pulang ke rumah Isai saat berlibur memberikan sebuah keinginan dan cita cita terdembunyi dalam diri Daud. Dalam penggembalan di padang gurun Daud belajar mempertahankan diri dan menjaga domba. Seni perang Daud mulai terasah dan lambat laun keberaniannya makin terpupuk matang. Dia bisa melawan musuh dan sekaligus bisa menyelamatkan diri dari tekanan musuh.

Hal lainnya adalah Daud pandai bicara dan elok perawakannya. Dalam bahasa terjemahan lain dikatakan bahwa Daud adalah pribadi yang penuh hikmat kebijaksanaan dan punya pembawaan yang menarik. Namun hal yang paling penting dan menjadi kesimpulan dari seluruh penilaian postif dari pegawai istana ini adalah Daud seorang yang disertai oleh Tuhan. Sisi kerohanian Daud sangat nampak dalam kehidupan sehari hari. Hal ini bisa diterima karena dalam tulisan Mazmur kita bisa melihat bahwa Daud tetap melakukan hal hal rohani yang menyenangkan Tuhan baik sebelum dan setelah menjadi raja bahkan sampai matinya. Kehidupan rohani yang 
dipupuk dari remaja saat hidup di padang gurun dalam menggembalakan tugas menjaga domba domba, telah memberikan nilai nilai tersendiri bagi Daud untuk dipersiapkan oleh Allah menjadi pemimpin yang menggembalakan bangsa Israel.

\section{KELAS KELAS KEPEMIMPINAN}

Ada beberapa hal yang bisa kita lihat nilai nilai Daud dalam kehidupan pribadinya:

\section{A. Gembala dan PelayananNya}

Setidaknya Tuhan mengajari Daud, seorang gembala kambing domba yang setia dari padang gurun Yehuda dan menjadi raja untuk menggembalakan bangsa Israel yang sangat besar lewat pengalaman hidup dan latar belakang Daud itu sendiri. Hal yang pertama adalah gembalakan bangsa Israel dengan ketulusan hati. (KJV; integrity of his heart). Kata lain ketulusan hati itu bekaitan dengan sebuah kata yang juga termasuk dalam leadership class yakni integritas.

Kamus Besar Bahasa Indonesia menjelaskan arti integritas adalah mutu, sifat, atau keadaan yang menunjukkan kesatuan yang utuh sehingga memiliki potensi dan kemampuan yang memancarkan kewibawaan; kejujuran. Ternyata integritas lebih menekankan kewibawaan integritas Ilahi dan kejujuran bagi seorang gembala.

David Bennett dalam Metafora of Ministry menunjukkan bahwa, dalam Alkitab, "gambar gembala adalah salah satu dari sedikit gambar yang diterapkan secara eksklusif kepada para pemimpin." Tidak kurang dari delapan kali dalam Perjanjian Lama, Allah digambarkan sebagai gembala umat-Nya. Dalam Injil, Yesus Kristus digambarkan sebagai gembala yang baik. Tidak ada guru atau model kepemimpinan yang lebih baik. ${ }^{10}$

Setidaknya ada delapan kualitas pemimpin gembala yang dapat kita pelajari dari gembala yang baik dalam Yohanes 10: 1-18 sebagai seorang pelayan Tuhan .

10 www.biblicalleadership.com/ Dec. 10, 2016 
1. Pertahankan batas yang jelas. Melangkahi batas-batas itu pasti akan merusak atau menghancurkan hubungan. Hal ini juga diterapkan gembala sebagai seorang pemimpin sejati. Untuk gembala, ada kandang domba di mana domba-dombanya berkumpul (10: 1-2). Hal ini untuk para pemimpin berbicara ada batas etika, moral, dan lainnya yang yang perlu ditetapkan.

2. Hiduplah menjadi contoh dan teladan yang baik. Pelayanan gembala adalah harus mempraktekkan kebenaran Alkitab terlebih dahulu dihadapan domba-domba dan domba-dombanya mengikutinya" (10: 3-4). Sedangkan sebagai pemimpin maka gembala bukan saja memberi contoh namun harus mampu menjadi model yang layak untuk diikuti.

3. Pribadi gembala dapat dipercayai. Domba mengikuti gembala dan pelayanannya karena mengenal dengan pasti kehidupannya sesuai dengan perkataannya, dalam jangka panjang dan relatif lama domba yang dilayani akan konsisten dengan segala pengajaran" (10: 4). Sebagai pemimpin gembala harus dapat perlu menumbuhkan rasa percaya dan komitmen yang mendalam dari domba yang dipimpinnya. Karkater kepemimpinan yang teruji akan membawa pengaruh besar terhadap kualitas orang orang yang dipimpinnya.

\section{Seorang gembala harus juga dapat memberikan pemenuhan} pemenuhan atas kebutuhan domba yang dilayani. Seorang gembala setidaknya dapat memberi arah ke padang padang rumput yang hijau (10: 9). Hal ini juga dituliskan dalam Mazmur 23 tentang apa yang menjadi kebutuhan domba secara mendetail. Sebagai seorang pemimpin, gembala juga harus dapat menajdi alternative untuk setiap kebutuhan domba yang "urgent". 
Bertindak dan merespon dengan benar, jangan sampai setiap keputusan pemimpin menghilangkan segi "kehidupan" dari yang dipimpin.

\section{Seorang Gembala mampu berkorban dengan tingkatan pengorbanan} yang semakin berat. Bukan saja bicara tentang jasmani atau batin namun juga soal nyawa. Demikian juga sebagai pemimpin, gembala harus rela bertanggung jawab untuk menghadapi musuh yang menyerang domba mereka.

6. Gembala harus mampu menginventasikan hidupnya buat domba. Sejahterakan kehidupan domba dengan menginventasikan waktu, tenaga, bahkan dana atau uang tanpa pamrih atau balas jasa. Jangan perhitungkan apa yang sudah dilakukan buat mereka karena Tuhan tidak akan pernah melupakan seluruh pelayanan ini. Jangan pernah menjadi gembala upahan yang melayani karena unsur gaji atau pemenuhan hidup, namun mengabdilah untuk Kerajaan surga dengan mahkota kemuliaan yang akan disediakan. 1 Peter 5:4 mengatakan "Maka kamu, apabila Gembala Agung datang, kamu akan menerima mahkota kemuliaan yang tidak dapat layu."

Demikian juga sebagai seorang pemimpin. Latih dan persiapkan domba menjadi calon pemimpin yang semakin baik di masa depan. Kelas kelas leadership berjenjang dan terstruktur harus dipersiapkan maksimal dari jenjang umur yang muda sampai dewasa.

\section{Gembala juga mampu untuk mejalin hubungan yang akrab dan intim} dengan domba. Yohanes 14 menuliskan "Aku mengenal domba-domba-Ku dan domba-domba-Ku mengenal Aku". Tidak ada jarak dan kekakuan yang terjadi. Rahasia pribadi menjadi sesuatu yang bisa dibagikan untuk didoakan dan dievaluasi. Sedangkan gembala sebagai pemimpin membangun hubungan 
yang dijalin dengan domba harus tulus dan kuat. Ciptakan hubungan yang mempunyai energy untuk dapat saling melengkapi dan membutuhkan, meskipuh hal ini akan dapat dicapai dalam waktu dan kesabaran yang relatif lama.

8. Gembala pada akhirnya mempunyai Visi yang jelas dan terarah. Yesus sebagai gembala punya visi untuk domba domba lain dari kandang ini. (ay 16). Demikian para gembala harus punya visi berkembang dan mendunia. Menjangkau domba domba melampaui keterbatasan dan kekurangan. Sedangkan sebagai pemimpin maka gembala harus mempunyai visi yang jelas dan yakin untuk mencapainya dengan misi misi selanjutnya.

\section{B. Kepemimpinan Seorang Gembala Yang diharapkan.}

Ada baiknya kita bisa kembali melihat kepada sejarah benua Amerika yang awalnya menjadi tempat pembuangan kaum Puritan Inggris yang akhirnya sekarang ini menjadi negara adi daya terbesar yang diakui di dunia. Tokoh terkenal seperti George Washington, Benjamin Franklin, John Adams dan juga Thomas Jefferson yang adalah merupakan nama nama dari sekian banyaknya presiden presiden Amerika yang pernah menjabat. Pertanyaannya adalah mengapa mereka begitu hebat kepemimpinan nya sehingga diakui oleh dunia? Darimana mereka mendapatkan pembelajaran dan pengalaman nya? Ternyata apa yang mereka dapatkan itu tidak lepas dari para bapa bapa endiri Bangsa Amerika yang memimpin dengan "hati sebagai gembala". Sejarah pendidikan sekolah di Amerika pernah mengalami 200 tahun pembentukan karakter di sekolah sekolah mereka dengan dua sumber utama yakni Alkitab dan New England Primer, yaitu cara cara pembelajaran bahasa Ingrris permulaan untuk sekolah dasar dengan penggunaan kata kata yang bersuku kata lebih dari empat seperti environment, extraordinary dan lain sebagainya. 
Bahkan cerita cerita dalam buku pelajaran pegangan mereka di kaitkan juga dengan cerita cerita Alkitab. Selain itu Continental Conggres America (Kongres Kontinental, juga dikenal sebagai Kongres Philadelphia, adalah konvensi delegasi yang dipanggil bersama dari Tiga Belas Koloni. Itu menjadi badan pemerintahan Amerika Serikat selama Revolusi Amerika) juga membeli 20.000 Alkitab untuk masyarakat umum pada waktu itu supaya dibaca. Menurut hasil dari Thomas Jefferson Research Institute dalam 200 tahun pertama Negara Amerika , 90\% sekolah bersifat religious, bermoral tingga dan punya etika kehidupan yang kuat. Namun hari hari ini Amerika telah kehilangan konsep da nisi hati pribadi dari "bapa bapa pendiri negara" yang begitu rohani memimpin dan menggembalakan mereka dengan Alkitab. Hingga pada akhirnya setelah melewati proses degradasi pembentukan karakter iman Kristen maka sekitar tahun1960 an Amerika menjadi negera yang anti Kristen. ${ }^{11}$ Dan hasil survey beberapa tahun yang lalu ternyata populasi Kristen di Amerika menurun hampir 8 persen antara 2007 dan 2014 dalam tingkat kedatangan beribadah. Dari sekitar $42 \%$ jumlah kedatangan aktif menjadi $35 \%$. Namun itu sudah dimulai terindikasi penurunan ini sejak tahun 1950an ketika hanya sekitar $50 \%$ saja orang percaya yang tetap aktif beribadah di gereja Tuhan per tahun.$^{12}$

\section{EFEK KEHILANGAN KEPEMIMPINAN DALAM PENGGEMBALAAN}

Penelitian yang lainnya di negeri yang sama menunjukkan setidaknya ada delapan alasan mengapa tingkat kekeristen di Amerika menurun drastis ${ }^{13}$. Hal yang menjadi penekanan adalah:

11 Ibid 159

12 David Guushe, "Why Is Christianity Declining”, (https:// https://religionnews.com / diakses tanggal 6 September 2016 
1. Kemunafikan dan konflik di gereja. Hal ini menjadi sedikit pelik bila terjadi di pucuk pimpinan gereja yakni gembala dan tim penggembalaan. Saat hal ini terjadi bukan saja membuat jemaat pindah gereja, seperti di masa lalu, tetapi kadang-kadang membawa justru membawa mereka keluar dari agama Kristen sama sekali.

2. Pudarnya Kekristenan kultural, yakni hilangnya harapan budaya atau kekeluargaan untuk berada di gereja atau mempraktekkan kekristenan dalam kehidupan sehari hari di Amerika. Keluarga gembala sering kali nampak tidak solid, beberapa diantara mereka justru bercerai. Ada kasus- kasus terlibat pelecehan seksual dalam rumah tangga. Beberapa kasus perkosaan dan pelecehan terjadi begitu menggemparkan dunia. Hal lainnya dapat dilihat dari anak gembala tidak sedikit yang terikat dengan narkotika dan obat obat terlarang, free sex dan tidak bermoral bahkan ada juga beberapa di antaranya tidak merasa beragama. Dan banyak lagi kisah- kisah lainnya yang bisa di ceritakan.

3. Kekristenan Amerika tidak menghasilkan banyak pemimpin yang meyakinkan, bahkan gagal menciptakan pemimpin rohani yang kelak menjadi "bapa bapa rohani" bagi generasi berikutnya. Kegerakan gembala untuk menciptakan banyak pemimpin berkualitas sepertinya terhambat berbagai faktor seperti self center, lebih fokus untuk hal-hal di luar gereja seperti radio, televisi, rumah sakit dan lain lain sehingga mengurangkan dan melupakan hal penting yang menjadi fokus utama gereja dan penggembalaan yakni membangun ke dalam, membangun manusia rohani itu sendiri.

Gembala dalam Penggembalaan nya masa kini selain terus memelihara prisip prinsip penggembalaan seperti Yesus yang sudah banyak dibahas dalam buku buku 
penggembalaan dan leadership training, maka ada beberapa hal yang ingin penulis tambahkan untuk menjadi referensi dan pemahaman yang bara. Hal yang pertama untuk diperhatikan adalah gembala hari hari ini selain punya hati hamba untuk melayani namun harus juga mempunyai mentalitas seorang tentara. Andrew W. Blackwood dalam teori penggembalaan ${ }^{14}$ menyatakan bahwa seorang gembala harus punya nilai sebagai seorang tentara di medan perang. Kondisi dan teks dari tentara yang dimaksud di sini buka sedang berlatih atau persiapan, namun sedang ada dalam medan peperangan. Doa, Saat Teduh, pujian dan penyembahan yang sehat dan terbaik merupakan menu sehari hari dari seorang gembala sebagai persiapan dalam peperangan rohani dihari itu. Jangan biarkan waktu, kesempatan dan motivasi seorang gembala terganggu dengan segala hal yang meyurutkan semangat peperangan rohani. Hal ini tidak berarti seorang gembala tidak menikmati waktu refreshing atau waktu luang, namun disaat yang bersamaan, seorang gembala juga harus mengenakkan seluruh selengkap senjata Allah. Efesus 6:11-12 menyatakan "Kenakanlah seluruh perlengkapan senjata Allah, supaya kamu dapat bertahan melawan tipu muslihat Iblis; 12 karena perjuangan kita bukanlah melawan darah dan daging, tetapi melawan pemerintah-pemerintah, melawan penguasapenguasa, melawan penghulu-penghulu dunia yang gelap ini, melawan roh-roh jahat di udara". Ayat selanjutnya memberikan arahan untuk mengambil dan memakai seluruh perlengkapan seorang tentara dalam peperangan. Bila terjadi kecerobohan atau ketertinggalan satu alat perang saja, bukan tidak mungkin kekalahan itu akan terjadi.

\footnotetext{
${ }^{14}$ Andrew W. Blackwood, " A Source Book For Minister" ( The Westminister Pres : Philadelphia 1945)
} 
Selain itu nilai lainnya yang bisa diambil dari seorang tentara adalah bahwa gembala harus bisa hidup teratur sebagai seorang perwira. Perwira disini adalah seorang tentara yang punya kapasitas seorang pemimpin. Dalam kesatuan Tentara Nasional Indonesia, seorang perwira yang paling rendah punya tingkat kepangkatan seorang Letnan Dua (ereka yang baru saja menyelesaikan akademi militer selama kurang lebih 3,5 tahun). Hal yang penting untuk diketahui oleh seorang bagi seorang perwira pertama ini yaitu mereka akan langsung punya tugas untuk menjadi pemimpin satu grup tersendiri yang sudah dipersiapkan namanya peleton dengan jumlah tentara yang siap berjuang di medan tempur $30-50$ tentara. $^{15}$

Sebagai seorang pemimpin gereja yang merupakan lembaga sebagai bagian dari Kerajaan Allah maka ada ketentuan ketentuan yang harus dilakukan oleh gembala dengan seksama, penuh dengan strategi dan juga pencapaian pencapain tertentu. Dia harus bukan saja ada di depan sebagai gembala yang memberi makan, memberi arahan dan memberi perlindungan kepada domba yang dilayani namun harus melatih seluruh domba dombanya untuk bisa "berperang" menghadapi kehidupan sementara di bumi ini. Perwira harus kuat dan tangguh, demikian juga seorang gembala. Perwira harus mahir untuk melihat kelebihan dan kekurangan anggota tentaranya, demikian pula seorang gembala dalam mengatur pelayanan di gerejanya. Seorang perwira menjadi seorang motivator yang ulung di medan perang untuk menaikkan semangat kesatuannya yang mungkin sedang ketakutan, kelelahan atau kebingungan, demikian juga seorang gembala dalam kotbah dan kesehariannya demikian. Bhakan seorang perwira harus rela mati untuk menolong anggota kesatuannya yang mungkin terluka, terjebak dalam sebuah situasi yang rumit dalam pertempuran, demikian juga gembala: engkau harus ada di sana turut merasakan dan

15 http://faculty.petra.ac.id/istilah_militer.html 
menjadi jalan keluar buat mereka. Jangan izinkan spirit ketakutan, kelemahan, keteledoran, kemalasan ada dalam kesatuanmu, demikian pula gembala aga baik baik domba seperti perwira supaya jangan biarkan spirit yang sama masuk dalam kehidupan rohani mereka.

Menurut riset dari penelitian tentang gembala atau pendeta pada tahun 2016 di USA ternyata dari 8015 orang gembala dari kalangan Injili dan Reformed, didapatkan hasil bahwa sekolah seminari atau sekolah Alkitab tidak mempersiapkan diri calon pendeta mereka untuk pelayanan penggembalaan seperti ini. Hasil survey mengejutkan sebanyak 53\% dari para gembala gembala menyatakannya. Hingga hal ini menjadi tidak mengherankan kalau banyak pendeta Amerika lulusan dari seminari - seminari Alkitab memang pintar untuk berkotbah dan berdebat tentang teologia namun mereka ternyata kurang terlatih berjuang hebat dalam melayani jiwa jiwa masuk dalam penggembalaan dalam jangka waktu yang lama. ${ }^{16}$

Penelitian ini juga memberikan sebuah kesimpulan yang berisi saran untuk perbaikan dalam kepemimpinan Gembala dalam gereja lokal. Pertama adalah Pendeta harus membangun formasi spiritual mereka sendiri sebelum mereka memimpin atau mengajar orang lain. Anda tidak dapat memimpin di mana Anda tidak tahu Jalan. Prinsip prinsip kehidupan dan kebenaran Firman Tuhan sudah terlihat jelas dari awal pelayanan. Hal kedua adalah Pendeta harus menumbuhkan iman mereka, menghabiskan setidaknya 30 menit sehari untuk pertumbuhan pribadi, membaca Alkitab, berdoa, dan devosi di luar persiapan mengajar. Lebih banyak lebih baik! Anggaran waktu itu! Saran ketiga yang disampaikan adalah Pendeta harus menyadari bahwa mereka tidak akan menyenangkan semua orang. Beberapa orang

${ }^{16}$ Dr. Richard J. Krejcir ," Statistics On Pastors" (https://churchleadership.org/diakses tanggal 10 Maret 2019) 
tidak akan menyukai Anda. Tidak apa-apa. berusahalah untuk menyenangkan Kristus, dan sisanya akan beres. Selanjutnya yang keempat adalah para pendeta atau gembala perlu melawan sikap apatis pribadi, keraguan, depresi, pesimisme, dan kepahitan. Hal kelima yang perlu dilakukan adalah pendeta atau gembala tidak harus menjadi pengasuh utama. Mereka harus atau memperlengkapi orang-orang untuk merekrut, melatih, dan memberdayakan sukarelawan dan pemimpin kelompok kecil untuk melakukan bagian terbesar dari pelayanan dan pelayanan pastoral. Dan hal keenam adalah untuk kesehatan dan pertumbuhan gereja yang optimal, gembala harus memiliki visi! Latih dan persiapkan mereka untuk punya visi yang besar, bertumbuh, cakupan luas dan mempermuliakan Tuhan.

Namun juga yang jangan pernah dilupakan adalah karakteristik kepemimpinan gembala itu sendiri. Hal ini sering kali menjadi sebab seorang gembala gagal untuk memimpin. Walaupun dia bisa memimpin gereja lokal namun sering kali berjuang keras untuk bisa menyelesaikannya. Dalam sebuah tulisan 10 Essential Characteristics of Church Leadership ${ }^{17}$ menyebutkan tentang 1). Komitmen untuk misi gereja, 2) karakter ilahi dalam setiap bidang kehidupan, 3) berkomunikasi secara efektif, 4) hati yang dapat diajar dan mau belajar, 5) fleksibel, 6) berorientasi pada tim, bukan perseorangan, 7) memimpin dengan memberi contoh, 8) menyelesaikan tanggung jawab yang ditugaskan.9) Punya pengaruh dalam keanggotaan, 10) Apakah mereka memiliki hati untuk melayani?

\section{KESIMPULAN}

\footnotetext{
Patricia " 10 Essential Characteristics Church Leadership", https://smartchurchmanagement.com/ diakses tanggal 9 november 2016)
} 
Gembala dalam tugasnya menuntun dan membawa jiwa jiwa untuk mengenal teladan Kristus dalam kehidupan seharai hari amatlah tidak mudah. Pembelajaran di sekolah teologia tidak cukup memadai. Namun diperlukan sebuah ketangguhan mental dan spiritual yang cukup dari seseorang yang telah dipanggil Allah untuk menggembalakan jiwa jiwa dengan sadar dan penuh pengabdian selama hidupnya.

Gembala bukan saja memiliki hati seorang hamba yang rela melayani dengan sungguh sungguh. Teladan Yesus menjadi tolak ukur penggembalaan yang alkitabiah sampai hari ini. Hati yang sungguh sungguh rindu untuk membawa jiwa jiwa dalam pertobatan yang sejati dan mengalami kehidupan yang damai dan tentram di tengah tengah carut marut kehidupan duniawi. Namun Yesus memberikan Roh KudusNya kepada setiap gembala dengan maksud yang lebih dari itu. Yesus naik ke Surga, Dia merindukan setiap anak anakNya untuk menggembalakan jiwa jiwa dengan lebih baik lagi dari waktu ke waktu.

Selain tugas gembala yang selalu identik sebagai pelayan Tuhan dalam tugas tugas gerejawi yang rutin, kini saatnya untuk gembala mempunyai porsi yang cukup lebih dan kuat khsusnya sebagai seorang pemimpin. Mungkin gembala sudah dipersiapkan dengan training leadership skill yang cukup. Namun kepemimpinan bukanlah bicara suatu hal yang statis, namun kepemimpinan bicara sesuatu hal yang dinamis seturut dengan perkembangan zaman yang selalu berubah dan tekanan tekanan kehidupan yang banyak mengalami deferensiasi. Kepemimpinan gembala tidak hanya kuat di dalam, namun pengaruhnya juga harus bisa dirasakan sampai keluar dari dinding gereja. Kepemimpinan gembala sekarang bukan hanya bicara tentang pelayanan yang baik dan seturut standar irman Tuhan namun juga harus sampai tujuannya kepada anak cucu generasi yang akan datang. Gembala harus mempersiapkan pelayanannya dengan sebaik mungkin namun juga dalam waktu 
bersamaan harus meningkatkan semangat dan nilai kepemimpinannya yang bisa menghadapi perkembangan zaman dan segala perubahan yang terjadi dan bisa menghancurkan kehidupan iman, harap dan kasih diantara orang percaya.

Pelayanan dan Kepemimpinan dari seorang gembala bukanlah menjadi sekedar sebuah motto yang enak untuk diingat, namun kedua hal di atas tersebut adalah sebuah nilai kehidupan Yesus yang harus menjadi identitas rohani dan jasmani dari setiap individu gembala yang telah dipanggil Tuhan secara khusus. Kegagalan dari nilai identitas ini akan membawa kapasitas orang percaya di akhir zaman menjadi tidak maksimal, namun bial dua hal ini dilakukan dengan sungguh sungguh dengan sikap hati pengabdian yang benar kepada Surga, maka gereja akan menuai , anak cucu dan generasi orang percaya di masa yang akan datang tidak akan pernah goyah sampai Yesus datang yang kedua kalinya. 


\section{DAFTAR PUSTAKA}

Blackwood Andrew W. "A Source Book for Minister" (The Westminister Press: Philadelphia 1945).

Lutzer, Erwin. "Pastor to Pastor" (Malang: Gandum Mas, 2010).

Barna George. “A Fish Out of Water” (Jakarta: Immanuel, 2004).

Wagner, Peter. "Memimpin Gereja Anda Bertumbuh" (Jakarta: BPK Gunung Mulia, $1995)$.

Sunkudon, Pieter G.O. Pilar- Pilar Kokoh Penopang Gereja (Palu: Sekolah Tinggi Teologi Injili Indonesia (STTII) Palu, 2013).

Ziglar, Zig. "Better than Good “(Integrity Publisher: Tennese, 2006)

\section{SUMBER LAINNYA}

Lori Mora, "Disayangkan Pendeta California Putuskan Bunuh Diri Karena Alasan Ini "https://www.jawaban.com/read/article/id/2018/08/28/90/180828144618/ (diakses 28 Agustus, 2018)

Danu Damarjati," Terjadi Lagi Pastor di Prancis Bunuh DIri Usal Tuduhan Pencabulan (diakses tanggal 23 Okotober 2018)

Dr. Richard J. Krejcir, "Statistic On Pastor" (Institute of Church Leadership Development: diakses dari https://www.intothyword.org/apps/articles)

Thom Rainer, "The Number One Reason For The Decline In Church Attendance And Five Ways To Addres It" , https://thomrainer.com/2013/08/the-number-onereason-for-the-decline-in-church-attendance-and-five-ways-to-address-it (diakses tanggal 19 Agustus 2013)

David "Wuushe, "Why Is Christianity Declining", https://religionnews.com/2016/09/06/why-is-christianity-declining (diakses 6 September 2016

Patricia "“ 10 Essential Characteristics Church Leadership", https://smartchurchmanagement.com/10-essential-characteristics-churchleadership (diakses tanggal 9 November 2016) 